\title{
UNA CARTA DEL ARQUITECTO IGNACIO DE CASTERA
}

En el año de 1786 se construía en Querétaro la interesante iglesia del Oratorio, terminada en 1802, por cuyo motivo los padres felipenses pidieron consejo al inteligente y entonces ya famoso arquitecto don Ignacio de Castera sobre las dimensiones que deberían de tener las iglesias y en particular la del Oratorio, que iba, según parece, en los cimientos. Castera contestó al padre Dimas Diez de Lara, por mediación de don Antonio de Lecca, la siguiente carta que creo de interés publicar.

Se encuentra unida al expediente del Oratorio de Querétaro en el Archivo General de la Nación, Sección Templos y Conventos, tomo 13.

$$
\text { F. de la } M \text {. }
$$

\section{Señor don Antonio de Lecca:}

Muy $S^{o r}$ mio: Remito a Ud. una sucinta explicación de los tamaños que corresponden a una iglesia, suplicándole me haga el favor de decirle a Ntro. querido $P^{e} D^{n}$ Dimas que siento mucho haverlos demorado y que no bayan con la extención que quisiera por estar todavia malo, por no estar de más nada para el acierto de semejantes Fábricas, pero vale que me avisará de qualesqra duda que tenga para suplir la poca prevención de todo lo que corresponde.

Aunque las dimenciones de una iglesia son diversas según el destino, como Cathedrales, Parroq", Ygles particulares etc., en nuestro caso me parece deberá elegirse el tercero assi por el destino que ha de tener como por aventajarse mucho en su construcción, circunst" muy interesante por no haver caudal fijo ni seguro para ella, por cuya razón siendo 14 varas de ancho, deve tener 56 de largo fuera de paredes, que se dividen en esta forma: 7 para el presbiterio, 14 para la media naranja o cimborrio, 
28 para el cuerpo de la iglesia y 7 para el coro. En la longitud de las 28 se construyen 4 bóvedas, o tres, según se quiera, con sus correspon ${ }^{\text {tes }}$ pilastras y arcos, los que llevarán una vara de de las 28 se construyen 4 bóvedas, o tres, según se quiera, con sus correspontes pilastras y arcos, los que llevarán una vara de ancho y lo mismo las pilastras, llevando éstas 14 de alto y 7 los arcos hasta la parte inferior de la clave. Los estribos que por la parte exterior corresponden a las pilastras han de llevar fuera del cuvo de la pared dos varas y de ancho una y media y de alto 16. Las paredes vara y quarta de grueso, arrojando de ellas las pilastras exteriores tres quartas. A los lados laterales del cimborrio sale la iglesia otras 7 varas pa formar el cruzero, cuyas paredes de testera bastará que tengan una vara, assi estas como las del presbiterio y fachada. Las bóvedas si son de piedra tres quartas de grueso en su principio, media en su clave; si son de ladrillo o tezontle, media en su principio, tercia y quatro dedos en su clave; los cimientos con una quarta más de cada lado del grueso expres ${ }^{\text {do }}$ en las paredes y estribos corridos por lo interior de una a otra pilastra y quatro varas de profundidad en donde haya tepetate firme, entendiéndose que este se ha de registrar, si es seguido o en ojas, dando varios taladros o barrenos o si se encontrase falso después del tepetate es preciso cortar las ojas y darle 6 varas de profundidad y 5 si la arena fuese seca y firme cuyas prevenciones me parecen sufictes para comenzar la obra interin ella misma va presentando dificultades de que podrá avisar.-Dios guarde a V. M. $\mathrm{m}^{\mathrm{a}} \mathrm{a}^{\mathrm{a}}$. De esta su casa y $\mathrm{Ag}^{\text {to }} 30 \mathrm{de}$ 1786. 